\title{
Modeling Forest Woody Biomass Availability for Energy Use Based on Short-Term Forecasting Scenarios
}

\author{
Ulises Flores Hernández ${ }^{1}$ (D) . Dirk Jaeger ${ }^{2} \cdot$ Jorge Islas Samperio $^{3}$
}

Received: 19 April 2018 / Accepted: 1 November 2018 / Published online: 8 November 2018

(c) The Author(s) 2018

\begin{abstract}
Bioenergy in Mexico offers a great potential as a transition strategy for introducing new energy supply chains. However, studies which focus on wood supply chains for bioenergy generation at a national level are scarce. Hence, this paper presents a model for predicting short-term availability of woody biomass for energetic use according to two scenarios. Scenario A exhibits business as usual conditions. In scenario B, the availability of forest woody biomass is improved by an increment in the areas of sustainably managed forest. The theoretical, technical and economic potentials of forest woody biomass availability for energetic use were assessed using (a) numerical modeling, (b) Holt-Winters exponential smoothing and (c) regression analyses Sustainability constraints and challenges such as soil degradation, terrain slope and mechanization level were considered. A regional case study was carried out, focusing on three species with the highest utilization rates (Pinus, Quercus and Abies). Setting the base at the year 2013, a forecast analysis for the year 2023 was performed. Under scenario B, for year 2023 a technical potential of 60.22 PJ was calculated, meaning an achievement of the goals set by the National Forestry Council regarding hectares under sustainable utilization. Furthermore, a net future value analysis was carried out to account the economic output during the forecasted period. Where comprehensive data was not available, the developed model was especially useful for predicting potentially available woody biomass for energy use.
\end{abstract}

Keywords Bioenergy $\cdot$ Sustainable forest management $\cdot$ Mexico $\cdot$ Simulation $\cdot$ Scenarios $\cdot$ Forest residues

\section{Statement of Novelty}

Studies which include the potential of forest woody biomass availability for energy use based on sustainability criteria in Mexico have not been performed at an upscale level. This research aimed to estimate the technical potential of supplying lignocellulose biomass for energy use from selected residues sources restricted by sustainability

Ulises Flores Hernández

ulises.flores@foresteng.uni-freiburg.de

Dirk Jaeger

dirk.jaeger@uni-goettingen.de

Jorge Islas Samperio

jis@ier.unam.mx

1 Chair of Forest Operations, University of Freiburg, Freiburg im Breisgau 79085, Germany

2 Department of Forest Work Science and Engineering, University of Göttingen, Göttingen 37077, Germany

3 Instituto de Energías Renovables, Universidad Autónoma de México, 62580 Temixco, Morelos, Mexico constraints as extraction limits given a short-term horizon. The implications of the study include the design of sustainable development programs for bioenergy generation that eases decision-making processes regarding diversification of by-products, policy guidelines and supply chain management for the forestry and energy sectors. When robust data is limited, the developed model adds innovation by allowing simulating outputs concerning forest woody biomass production, hectares under sustainable forest utilization, round-wood imports, energy generation and economic flows of utilization.

\section{Introduction}

National energy production and supply have relied mainly on oil exploitation. In the last decade, Mexico increased its oil production until it reached its peak in 2004. According to the National Energy Ministry (SENER), by the end of 2013 Mexico produced 2.505 million barrels per day (mbd) and, due to diminishing resources, this will decrease to 1.048 
mbd by 2027 . This amounts to a $52.8 \%$ reduction in production during this period [1]. There is an estimated relevant future potential for the exploration and exploitation of oil areas within the national territory, which would result in oil availability for the next 17 years. Nevertheless, although investment in exploration and hydrocarbon production has increased more than three times during the last 12 years, proven oil reserves decreased by $31.2 \%$ [2]. Since oil production is limited by restricted resources and is therefore not sustainable perse, a transition to a national energy mix that includes renewable energy sources appears to be a feasible means of addressing the situation. With the development of renewable energy projects at a national level, analyses of the potential diversification of energy supply chains in Mexico have had a principal focus on solar power, wind energy and some biomass sources, barely considering the advantages of sustainable forest utilization of woody biomass as an input for energy systems. Sustainable forest utilization is referred as to a balance to maintain forest health, biodiversity, productivity, regeneration capacity, vitality and the potential to meet the demand of forest products. This is accomplished by ensuring that only biomass increment can be harvested, for example. To date, research about the integration of the forest value chain towards forest utilization for bioenergy transformation in Mexico has been marginal.

The SENER estimated an increase in bioenergy generation of 746 MW by 2026, revealing its potential for contributing to the national energy supply. The energy production objective for 2024 aims at producing $35 \%$ of electric power from clean technologies, including $21 \%$ from renewable energies, $23 \%$ nuclear power and $25 \%$ from clean energies (the remaining $31 \%$ comes from other sources such as hydro power). According to the SENER, clean technologies involve not only renewable energies but also non-fossil energies, such as nuclear energy, and fossil energies with $\mathrm{CO}_{2}$ capture. The so called clean energies with $\mathrm{CO}_{2}$ capture are referred to as clean coal-fired power plants. Furthermore, a target of $20 \%$ electric power generation from renewable energies by the end of 2018 has been set [3]. Associated with this, some studies about the availability of woody biomass have been conducted. However, analyses of the availability of biomass should include scenario analysis of future availability to assure sustainability of supply.

According to the Mexican government, biomass use in Mexico represents a great opportunity for the production of competitive electricity with low environmental impacts [3]. By the end of 2013, there were 66 bioenergy power plants in Mexico representing significant historical improvement in the utilization of biomass [3]. Nevertheless none of these included the utilization of forest woody biomass as a source of bioenergy. Bioenergy from woody biomass and related supply chains open new horizons for forest utilization which could positively impact regional bio-economies.
The extended forest land base in Mexico has a high potential for sustainable supply of woody biomass. The National Forestry Council (Comision Nacional Forestal, CONAFOR) [4] estimated that Mexico's forested area is approximately 63 million hectares, which represents $47 \%$ of the national vegetated surface. This coverage included $41.2 \%$ of xeric shrublands, $24.2 \%$ of temperate forest, $22.8 \%$ of tropical forests and $11.8 \%$ of other forest vegetation. However, only $15.1 \%$ of the total forested area is under management [5]. The Mexican forest sector has undergone several changes with a slight increase of sustainably managed forest land and an increase in wood production due to changes of forest management practices and to a slight improvement in productivity. According to Torres [5], these changes have been possible due to a shift of selective methods towards more intensive cultivation methods, which have been supported by national forest development programs. Still, the current situation is represented by a lack of integration along the value chain for managing, transforming and developing a sustainable market for the industry. Furthermore, the need for labor in harvesting activities has increased too, although cost and productivity have remained similar. The machinery for extraction is generally represented by cranes and recently some cable yarding projects have started to be introduced [6].

Since 2001, increased national timber demand has affected the commercial and industrial balance. Back in 2004 , only $39 \%$ of the national timber demand was met through national production [7]. In 2014 approximately $71 \%$ (16.4 million cubic meters) of the timber products consumed in Mexico were imported, indicating vast opportunities for the development of domestic clusters which could transform the sector into a sustainable and profitable industry [7]. There is a need for research that integrates sustainable forest utilization for bioenergy supply in Mexico in regard to biomass availability and energy output given a time frame. To date, studies about energy availability from forest woody biomass in Mexico present results based on scenarios considering different variables and methodologies. For instances, based on an evaluation supported by an analysis on GHG mitigation and costs, García et al. [8] calculated an energy potential of $64 \mathrm{PJ} /$ year from wood pellets burned for heat and $108 \mathrm{PJ} / y$ ear from traditional wood-fuel for efficient cook stoves. Furthermore, using a high spatial distribution approach, Rios and Kaltschmitt [9] pointed to a bioenergy potential of 638 PJ from forest and shrub woody biomass residues and $26 \mathrm{PJ}$ from woody industry residues for the year 2010. Islas et al. [10] presented a technical potential for 2004 of $71 \mathrm{PJ} / \mathrm{year}$ from sawmill residues and harvesting residues, 997-1791 PJ/year from natural forest and 450-1246 PJ/year from plantations. Unlike these studies, the methodology developed in this research considered forest management criteria as sustainability constraints based on 
extraction limits. That is to say, it took into consideration harvesting constraints to estimate technically available biomass for energetic use, including estimations of productivities according to equipment and mechanization level, all of these using a regional scenario analysis within a time frame. Several papers regarding the assessment of forest biomass supply chains present and discuss frameworks for modeling variables which estimate output in terms of biomass availability, costs and C stocks and fluxes [11-14]. Additionally to the frameworks, methods and tools of these studies, and based on available national and regional data from forested land, this research proposed a comprehensive evaluation of the Mexican forest sector with a particular focus on forest parameters for bioenergy supply. This research aimed to estimate the technical potential of supplying lignocellulose biomass for energy use from selected residues sources restricted by sustainability constraints as extraction limits. Thus, this paper presents a methodology based on numerical modeling with the objective to forecast availability of forest woody biomass for energetic use given a short-term horizon. Outputs and results allow for the analysis and the evaluation of the potential of sustainable biomass supply from the forest and energy sector in Mexico.

\section{Materials and Methods}

The methodology presented in this research included sustainability constraints by considering biomass extraction limits based on soil conditions, slope percentage and mechanization level. In order to estimate forest woody biomass availability over a short-term time frame and taking into account sustainability constraints, this research considered a comparison between two scenarios for the years 2013-2023: Scenario A (Business as usual (BAU)) and scenario B. Scenario A exhibited business as usual behavior and followed a trend based on historic and status quo conditions. For this scenario, the methodology included the development of regression analyses for estimating the number of hectares needed to achieve a certain level of timber production, which was calculated based on forecasting methods. In scenario B, the availability of forest woody biomass was improved by an expansion of sustainably managed forest. Once predictions were carried out for both scenarios, numerical modeling developed by Flores Hernandez et al. [15] for calculating the theoretical, technical and economic potential of woody biomass availability for energetic use was performed. These potentials were assessed within three research modules: (i) Availability and appropriateness of lignocellulose biomass, (ii) Forest management for bioenergy supply and (iii) Energy output [15]. The research accounted for three sources of woody biomass:
(1) Residues from timber harvesting operations It included woody biomass that was left on site after harvesting operations, including badly shaped logs, logs not reaching the standard diameter for transformation (between 2.5 and $12.5 \mathrm{~cm}$ diameter) and branches with no commercial use.

(2) Residues from non-extracted stands These were remaining stands that were marked for utilization but were not harvested according to the management plan. Only wood residues were considered from these stands. This assumed that wood residues from these stands were available according to the extraction limits given the sustainability constraints

(3) Residues from sawmills This referred to wood pieces with no commercial use after sawmill processing, in the form of cuts, strips and sawdust. Residues from milling wood imports were also taken into consideration. It should be noted that for residues from sawmill imports a baseline period was set using $4,961,526 \mathrm{~m}^{3}$ in 2013 as the fixed theoretical availability. This assumed that sawmill imports were directed affected by national availability of residues coming from sawmills. That is to say, for years following 2013 , if the theoretical availability of residues coming from sawmills is less than the actual sum of the sawmill residues from both regions, then imports are equal to cero. Otherwise, the sawmill imports are equal to the baseline timber imports minus the sum of sawmill residues from both regions.

These three sources originated from private forest and forest owned by communities, excluding natural protected areas. Potentially available woody biomass from milling residues of imported timber was estimated based on import values of round-wood reported by the national statistical yearbook of forest production from 2013. Moreover, a spatial approach based on two clusters at a province level was carried out, including 10 out of 32 provinces in northern and central south of Mexico comprising areas with the highest timber utilization at a national scale. From the northern region the provinces of Durango and Chihuahua, and from the central-south region the provinces Michoacán, Oaxaca, Puebla, Veracruz, Chiapas, Guerrero, Jalisco and the state of Mexico were considered. Based on highest timber production rates at a national level, the analyzed tree species were Pinus, Quercus and Abies. According to data availability, available studies and data significance from year 2013 including forestry, economic and geographical input values, year 2013 was set as base line year. Numerical modeling, Monte Carlo simulations, Holt-Winters exponential smoothing and regression analyses were the integrated tools for calculating the theoretical, technical and economic bioenergy potential. These methods were selected due to limitations on 
available data for running the developed model. Thus, due to constraints on availability of robust data, statistical methods were also considered in order to simulate scenarios within a short-term horizon. The model is described as follows:

\section{Numerical Modeling for Assessing Theoretical, Technical and Economic Potential of Forest Woody Biomass Availability for Energetic Use}

Based on the methodology developed by Flores Hernandez et al. [15], numerical modeling was undertaken to develop equations for estimating biomass availability as well as extraction limits according to sustainability constraints (See Appendix A). Based on the interconnection between the research modules, the study integrated an analysis of theoretical, technical and economic potential to assess of energy output. The model used timber utilization data of recent years, together with geographical and historical data from governmental reports as an input to determine the potentials. The core components, based on [15], are generally described below:

(1) A spatial approach was applied that delimits the geographical area of analysis with $i$ as the analyzed species out of an $n$ number of species in a $j$ region or site based on land use and inventory data (See Appendix B).

(2) At a theoretical and technical level, equations for estimating available woody biomass as well as extraction limit equations were developed for numerical modeling (see Appendix A) [15] using coefficients from literature together with statistical and geographical data. These were:

Coefficient for harvesting residues $(C)$ It considered the volume of woody biomass in cubic meters remaining after timber harvesting as residues on site. Values were estimated as rates of the harvested stem volume, using 0.18 for pine, 0.35 for oak and 0.19 for fir [16].

Coefficient for non-extracted residues (Cne) It accounted for an area rate of non-extracted stands of the total analyzed area as residues, using factor of 0.10 for conifers and of 0.27 for Quercus [16].

Coefficient for sawmill residues (Cs) It was used for comprising the available volume of biomass residues from sawmill processing based on the milled roundwood volume. A residue biomass coefficient of 0.41 was used for conifers. The sawmill residues volume for oak was calculated using 0.53 as coefficient [16].

(3) GIS spatial analysis involving digital elevation models (DEM) from the analyzed provinces was used to analyze terrain slope in order to calculate sustainability constraints with respect to timber harvested and extraction operations.
(4) To determine economic potential, stochastic simulations were developed in order to estimate the production cost resulting from utilization and transportation. Using statistical sampling to represent uncertainties by specifying inputs as probabilistic distributions, the estimation of associated costs for utilizing available woody biomass for energetic use was performed using the Monte Carlo method. These uncertainties were observed in the model as differences between the economic performance of the forest sector in the north and central-south region, as well as parameters such as infrastructure and market development. Therefore, the Monte Carlo method was used to estimate costs and treat uncertainties due to differences between regions. This method uses aleatory generated values to model and simulate processes in order to estimate complex outputs. Monte Carlo simulation accounts for uncertainties in the data and assumptions. That is to say, random samples are considered from assumed distributions of an uncertain parameter, to make estimations for each set of random values. The procedure is carried out as many times as is necessary for the changes in the sample means and variances to converge within the desired tolerances [17]. Based on information and data from 27 community forest enterprises, distributed on 12 provinces along the country, statistics parameters were taken and costs were calculated [18] (Table 1). These costs included: (1) labor cost from harvesting and extraction, (2) labor cost from machine operation, (3) road maintenance and construction cost, (4) transportation cost and (5) technical support cost.

Furthermore, prices from the national system of forestry information from the final trimester of 2013 for both regions were taken into account together with the estimated costs from the Monte Carlo simulations. A net future value analysis (NFV) of alternatives was then performed [17].

For both scenarios, a (F/P) factor given an interest rate of $5 \%$ in 10 years equal to 1.6289 was used, together with estimated costs and selected timber prices (Table 2). It should be noted that for the non-extracted stands residues, only residues were taken into consideration for the calculation within the economic analysis, while industrial wood was allocated for higher value utilization.

In this research, sustainability constraints were defined as forest parameters relating to technical, economic and operational restrictions which limit biomass availability for energetic use. These are detailed explained by Flores Hernández et al. [15] and briefly described as follows:

Terrain slope In order to calculate the technical biomass constrained by terrain slope condition, a terrain slope class calculation per region was carried out using GIS spatial analysis based on five slope classes [19]. Only areas with 
Table 1 Statistics parameters from sampled data according to cost and region

\begin{tabular}{lcclcc}
\hline & $\begin{array}{l}\text { Labor cost } \\
\left(\mathrm{USD} / \mathrm{m}^{3}\right)\end{array}$ & $\begin{array}{l}\text { Machine operation } \\
\text { cost }\left(\mathrm{USD} / \mathrm{m}^{3}\right)\end{array}$ & $\begin{array}{l}\text { Road cost } \\
\left(\mathrm{USD} / \mathrm{m}^{3}\right)\end{array}$ & $\begin{array}{l}\text { Transportation } \\
\text { cost }\left(\mathrm{USD} / \mathrm{m}^{3}\right)\end{array}$ & $\begin{array}{l}\text { Technical support } \\
\text { cost }\left(\mathrm{USD} / \mathrm{m}^{3}\right)\end{array}$ \\
\hline North $\mathrm{n}=20$ & & & & & \\
Min & 0.69 & 2.14 & 0.08 & 6.66 & 0.92 \\
Max & 16.16 & 18.76 & 6.66 & 24.27 & 4.75 \\
Range & 15.47 & 16.62 & 6.58 & 17.61 & 3.83 \\
SD & 5.26 & 6.32 & 2.26 & 6.68 & 1.55 \\
Average & 4.98 & 12.44 & 1.68 & 13.05 & 3.08 \\
Central south $\mathrm{n}=7$ & & & & & \\
Min & 2.07 & 0.08 & 0 & 6.13 & 0.08 \\
Max & 91.04 & 41.81 & 5.67 & 44.10 & 18.61 \\
Range & 88.97 & 41.73 & 5.67 & 37.98 & 18.53 \\
SD & 20.03 & 11.87 & 1.65 & 8.63 & 5.16 \\
Average & 17.06 & 11.81 & 2.08 & 18.45 & 5.98 \\
\hline
\end{tabular}

Table 2 Prices and costs involved in calculating the NFV of alternatives for year 2023

\begin{tabular}{llll}
\hline & $\begin{array}{l}\text { Harvesting } \\
\text { residues (USD/ } \\
\left.\mathrm{m}^{3}\right)\end{array}$ & $\begin{array}{l}\text { Non-extracted } \\
\text { stands and residues } \\
\left(\mathrm{USD} / \mathrm{m}^{3}\right)\end{array}$ & $\begin{array}{l}\text { Sawmill } \\
\text { residues } \\
\left(\mathrm{USD} / \mathrm{m}^{3}\right)\end{array}$ \\
\hline $\begin{array}{l}\text { Price } \\
\text { North }\end{array}$ & 45.55 & 45.55 & 59.22 \\
Central-south & 35.00 & 35.00 & 59.11 \\
$\begin{array}{l}\text { Cost } \\
\text { North }\end{array}$ & 34.12 & 40.55 & 23.91 \\
Central-south & 62.38 & 74.94 & 44.62 \\
\hline
\end{tabular}

a slope up to $35 \%$ were considered in the analysis. This is based on the terrain classification system for forestry given by Berg [19] and the limitation set by Manolis et al. [20], where biomass beyond $35 \%$ of slope is not accessible given restricted forest operations techniques.

Soil degradation Physical and chemical soil degradation represented by compaction and fertility of soil were assessed. Equations to identify extraction limits were developed using inventory data and numerical modeling (see appendix A). In addition, historical data on land use for each province were analyzed. Extraction limit factors were calculated setting slight, moderate and severe as protection measures to reduce degradation risks. These limits were based on information collected in a literature review together with national inventory data and the "Evaluación de la degradación del suelo causada por el hombre en la República Mexicana" (Assessment of soil degradation caused by man in Mexico) [21]

Mechanization level This included a productivity assessment of harvesting operations considering equipment, slope percentage at felling site and diameter at DBH of the stand to be felled. The harvesting cycle included felling, debranching and bucking. Equation (1) presents productivities in manual harvesting operating with chainsaws for the analyzed species at a national level (adapted from [11]). As shown in Eq. (2), a D factor was calculated based on harvesting coefficients, affecting productivities according to the amount of biomass residues from harvesting activities.

$\operatorname{Pr}_{i}=\left[\frac{42-2.6 \times D B H}{-20} \times 1.65\left[1-\frac{S l}{100}\right]\right] \times D_{i}$

$D_{i}=1+\left(C_{i}-C_{\text {pine }}\right)$

where $\mathrm{Pr}$ is the productivity of manual felling using chainsaw $\left(\mathrm{m}^{3} / \mathrm{h}\right), \mathrm{Sl}$ is the terrain slope at the felling site (\%), DBH correspond to the diameter of felled trees at breast height (cm) and $D$ is the correction factor based on $C$ as coefficient residue from total harvested stem volume for a species $i$ and $C_{\text {pine }}$ is the coefficient from harvesting residues for pine.

In order to treat uncertainties due to differences in the analyzed forest land, a case study with two regions for three particular species was conducted. That is to say, analyses for each species and each region considering individual regional variables were performed. As it is the moisture content of wood rather than the species that determines energy availability, a net heating value of $16.0 \mathrm{GJ} / \mathrm{t}$ was set. This assumed air-dry wood with $15 \%$ of moisture content wet basis [22]. Basic dry wood densities were set to $0.487 \mathrm{t} / \mathrm{m}^{3}, 0.740 \mathrm{t} / \mathrm{m}^{3}$ and $0.380 \mathrm{t} / \mathrm{m}^{3}$ for pine, oak and fir respectively [23]. As presented before, for predictions, a time horizon from 2014 to 2023 was considered. Moreover, the developed methodology for each scenario is explained in detail below.

\section{Scenario A}

Scenario A considered a simulation based on BAU conditions. Results were calculated using the Holt-Winters exponential smoothing forecast method, regression analyses and the previously explained numerical modeling. Step 1: In order to build a times series for timber 
production, data from the national statistical yearbook of forest production (1993-2013) was used for pine, oak and fir according to northern and central south regions. This dataset was used as an input for applying the Holt-Winters exponential smoothing method for projecting forest production to 2023 [24-26]. This method involved a forecast equation and three smoothing equations, one for the level $\mathrm{lt}$, one for trend bt, and one for the seasonal component denoted by $s t$, together with smoothing parameters $\alpha, \beta$ and $\gamma$. It uses $m$ to represent the period of the seasonality, for example, $m=12$ for monthly data with 1 year of analysis [27]. As the seasonal variations of the analyzed series change proportionally with its level, a multiplicative method was used according to [27]. Since this study does not attempt to describe or discuss the forecast method in detail, the component form of the forecast is generally referred to [27]. Step 2: Based on data from the document "Competitiveness and market access of community forest enterprises in Mexico" regression analysis equations to predict the number of hectares needed to achieve the forecasted production from Holt-Winters exponential smoothing was estimated. Biomass production $\left(\mathrm{m}^{3}\right)$ as the independent variable and production areas (ha) as the dependent one were the analyzed variables with a sampling universe of seven enterprises for the northern region and 20 for the central south region [18]. In order to assess the validity of the linear regression model, an Analysis of Variance (ANOVA) together with the estimation of coefficient of multiple correlation (R) and the coefficient of determination $\left(\mathrm{R}^{2}\right)$ were carried out. Using an F-test to test the relationship between the variables and a student- $t$ test to test the regression coefficients, the linear regression was assessed. The analyses were carried out separately by species and region. Then, regression equations were related to the forecast by using the forecasted timber production from step 1 as the independent variable. In this way the production areas required to achieve the predicted timber volume were calculated.

Step 3: Available data regarding the mean annual increment (MAI) of the examined species from national reports was included on the forecast model. The National Forest and Soil Inventory 2004-2009 presents respective MAIs for three important conifers in the country: Pinus, Pseudotsuga and Abies. Based on this data, a MAI of $1.99 \mathrm{~m}^{3} /$ ha/year for conifer forests was used, while for mixed conifers and broadleaved forests MAI of $1.88 \mathrm{~m}^{3} /$ ha/year was set [4]. The MAI was then multiplied by these hectares resulting in the available lignocellulose biomass as total yearly increment (TYI).

Step 4: Subsequently, numerical modeling to assess the theoretical, technical and economic potential of forest biomass for energetic use [15], was carried out.

\section{Scenario B}

In order to compare alternatives, scenario B was developed. This comprised an estimate of production areas assuming a $1 \%$ annual increment of managed forest land followed by a growth based on an arithmetic gradient.

Step 1: Historical data from the national statistical yearbook of forest production shows the size of aggregated approved harvesting areas (in ha) per year, which varied from 7745 ha in 2010 to 8482 ha in 2014. Largest harvested areas of 17,027 ha and 15,376 ha were observed in 2008 and 2012 respectively. Based on these data, a conservative arithmetic gradient of an approved increased of harvesting area of 2500 ha per year was determined. Furthermore, the arithmetic gradient ant the assumed rate of increment were set based on the goal established by the National Forestry Program 2014-2018 to increase the national timber production to $11,000,000 \mathrm{~m}^{3}$ by 2018 meaning a growth of $186.13 \%$ with 2012 as the reference year. The predictions are explained by the following equation:

$A s=P(1+i)^{n}+G\left[\left(\frac{1}{i}\right)\left(\frac{(1+i)^{n}-1}{i}-n\right)\right]$

where $A s$ refers to the predicted hectares under sustainable utilization for scenario $\mathrm{B}$ (ha), $P$ is the present number of hectares currently utilized (ha), $i$ is the assumed rate of increment in hectares under sustainable utilization (\%), $n$ is the number of analyzed years and $G$ is the arithmetic gradient of approved harvesting areas under sustainable utilization (ha). The projection was also done for year 2023.

Step 2: Once the predicted hectares under sustainable utilization have been estimated, these were multiplied by the MAI in order to calculate the total yearly increment.

Step 3: Numerical modeling to assess the theoretical, technical and economic potential of forest biomass for energetic use was then carried out.

\section{Results}

\section{Scenario A}

Step 1: To measure the accuracy of the forecast model based on Holt-Winters exponential smoothing, the mean error (ME), mean absolute deviation (MAD), mean absolute percentage error (MAPE) and the mean square error (MSE) were estimated against different smoothing parameters (Table 3 ).

The selected smoothing parameters presented in Table 3 had the lowest MSE which is generally used to assess the quality of a prediction model. Differences by region and 
Table 3 Smoothing parameters and measurements for forecast error for northern and central south regions for scenario A for the Holt-Winters exponential smoothing model

\begin{tabular}{llllllll}
\hline Model & $\alpha$ & $\beta$ & $\gamma$ & ME & MAD & MAPE & MSE \\
\hline North & & & & & & & \\
Pine & 0.99 & 0.05 & 0 & $-73,335.24$ & $264,826.02$ & $9 \%$ & $9.29 \mathrm{E}+10$ \\
Oak & 0.47 & 0.44 & 0.41 & $22,632.13$ & $66,535.70$ & $23 \%$ & $6.38 \mathrm{E}+09$ \\
Central south & & & & & & & \\
Pine & 0.99 & 0.12 & 0 & $-70,580.20$ & $255,253.71$ & $11 \%$ & $1.15 \mathrm{E}+11$ \\
Oak & 0.8 & 0.42 & 0.15 & $13,149.35$ & $57,418.60$ & $28 \%$ & $6.66 \mathrm{E}+09$ \\
Fir & 0.99 & 0 & 0 & -4825.33 & $42,100.90$ & $24 \%$ & $3.16 \mathrm{E}+09$ \\
\hline
\end{tabular}

species are due to variabilities of forestry parameters such as round wood production, sawmill production, mean annual increment, areas under utilization and total forest area.

Step 2: The linear regression analysis of production areas (ha) (PA) as the dependent variable and production $\left(\mathrm{m}^{3}\right)$ as the independent one to predict the required size of production area resulted in the regression Eqs. (9) and (10). Equation (4) predicted the number of hectares required for the northern region to meet a production indicated by the independent variable $\mathrm{x}$. Equation (5) represented the prediction for the central south region.

$H n=-4,000.46+0.7972 P n$

$H c s=2,278,94+1.2214 P c s$

where $H n$ are the predicted hectares for the northern region, $P n$ is the forecasted production for the northern region, Hcs are the predicted hectares for the central south region and $P c s$ is the forecasted production for the central south region.

For the northern region, the coefficient of determination $\left(\mathrm{R}^{2}\right)$ showed that $60 \%$ of the variation of the dependent variable (production area) was explained by the independent variable (production). For the central south region the variation of the production areas was $61 \%\left(\mathrm{R}^{2}\right)$ which was explained by production. Therefore, for the two regions, the model was significant for predicting required production areas.

Step 3: Within a short-term time of 10 years, for the northern region the production area (PA) of pine decreased to $1,422,035$ ha in total, while oak increased to 178,092 ha. A similar trend was observed for the central south region, affecting the total yearly increment too (Fig. 1).

Step 4: After numerical modeling was run based on inputs from Holt-Winters exponential smoothing and regression analyses, the available energy coming from residues of forest

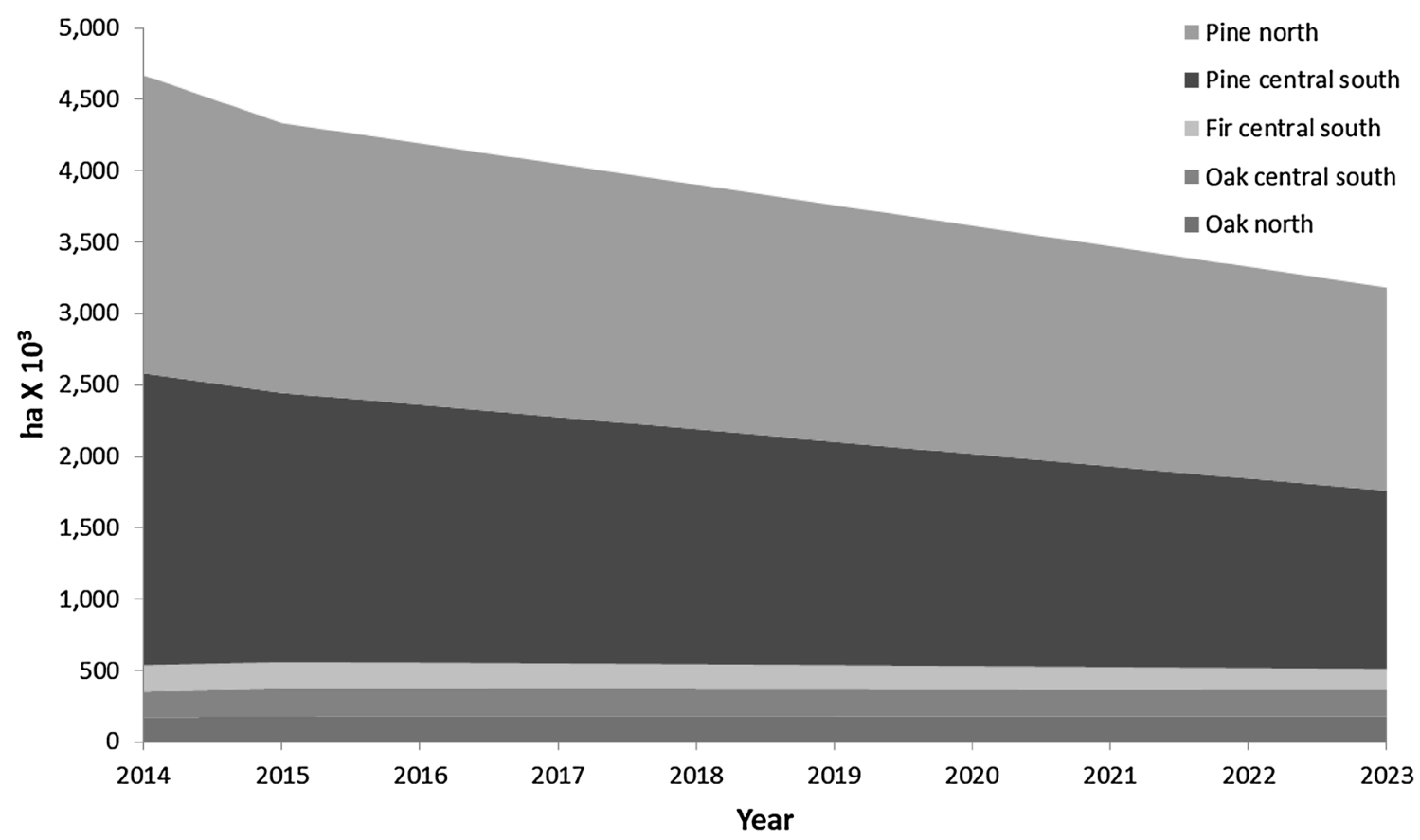

Fig. 1 Development of productive forest land (2014-2023) based on Holt-Winter exponential smoothing, regression equations and MAI for the analyzed species by region in Scenario A 
Table 4 Technical availability of woody biomass constrained by soil degradation, slope percentage and mechanization level $\left(\mathrm{m}^{3}\right)$ for 2023 in Scenario A

\begin{tabular}{lrllr}
\hline Source & Pine & Oak & Fir & \multicolumn{1}{l}{ Total } \\
\hline Harvesting residues $\left(\mathrm{m}^{3}\right)$ & & & & \\
North & 350,087 & 80,540 & - & 430,627 \\
Central-south & 307,582 & 82,947 & 38,724 & 429,253 \\
$\quad$ Total & 657,669 & 163,487 & 38,724 & 859,880 \\
Non-extracted stands $\left(\mathrm{m}^{3}\right)$ & & & & \\
$\quad$ North & 700 & 1845 & - & 2546 \\
Central-south & 969 & 2626 & 1369 & 4963 \\
$\quad$ Total & 1669 & 4471 & 1369 & 7509 \\
Sawmill residues $\left(\mathrm{m}^{3}\right)$ & & & & \\
$\quad$ North & 788,437 & 48,964 & - & 837,401 \\
Central-south & 692,711 & 50,427 & 86,960 & 830,098 \\
Imports & & & & $3,294,027$ \\
$\quad$ Total & $1,481,148$ & 99,391 & 86,960 & $4,961,526$ \\
Total & & & & $5,828,914$ \\
\hline
\end{tabular}

Table 5 Technically available energy from forest woody biomass (PJ) for 2023 in Scenario A

\begin{tabular}{lccll}
\hline & Pine & Oak & Fir & Total \\
\hline North & 8.88 & 1.56 & - & 10.43 \\
Central-south & 7.80 & 1.61 & 0.77 & 10.18 \\
Sawmill imports & & & & 25.67 \\
Total & 16.68 & 3.17 & 0.77 & 46.28 \\
\hline
\end{tabular}

woody biomass over a period of 10 years was analyzed. The results showed a slight decrease, from 49.05 PJ in 2014 to 46.28 PJ in 2023 (Table 5). After the model was run, and biomass extraction limits based on sustainability constraints were applied, a technical potential of $5,828,914 \mathrm{~m}^{3}$ of available biomass for year 2023 was estimated (Table 4).

When analyzing the time series for the forecasted years, the volume of imported timber increases over time (Fig. 2) whereas a smooth but continuous decrease in the amount of available energy takes place. This scenario assumed that soil degradation remains at 2013 levels and also that the level of mechanization remains constant. As such, extraction limits were constant.

\section{Scenario B}

Once results for scenario A had been calculated, scenario B comprising constant expansion of productive forest land under sustainable utilization was analyzed. Step 1: Eq. (3) was used to estimate the annual increment of productive forest land. A total of 4,166,749 ha and 3,733,987 ha as productive areas for year 2023 for the northern region and central south region respectively were calculated.

Step 2: Productive areas and total yearly biomass were calculated for each species and each region, resulting in an increase of available volume of timber. Results pointed out a total of 7,900,736 ha for the total regional case study for year 2023 (Fig. 3).

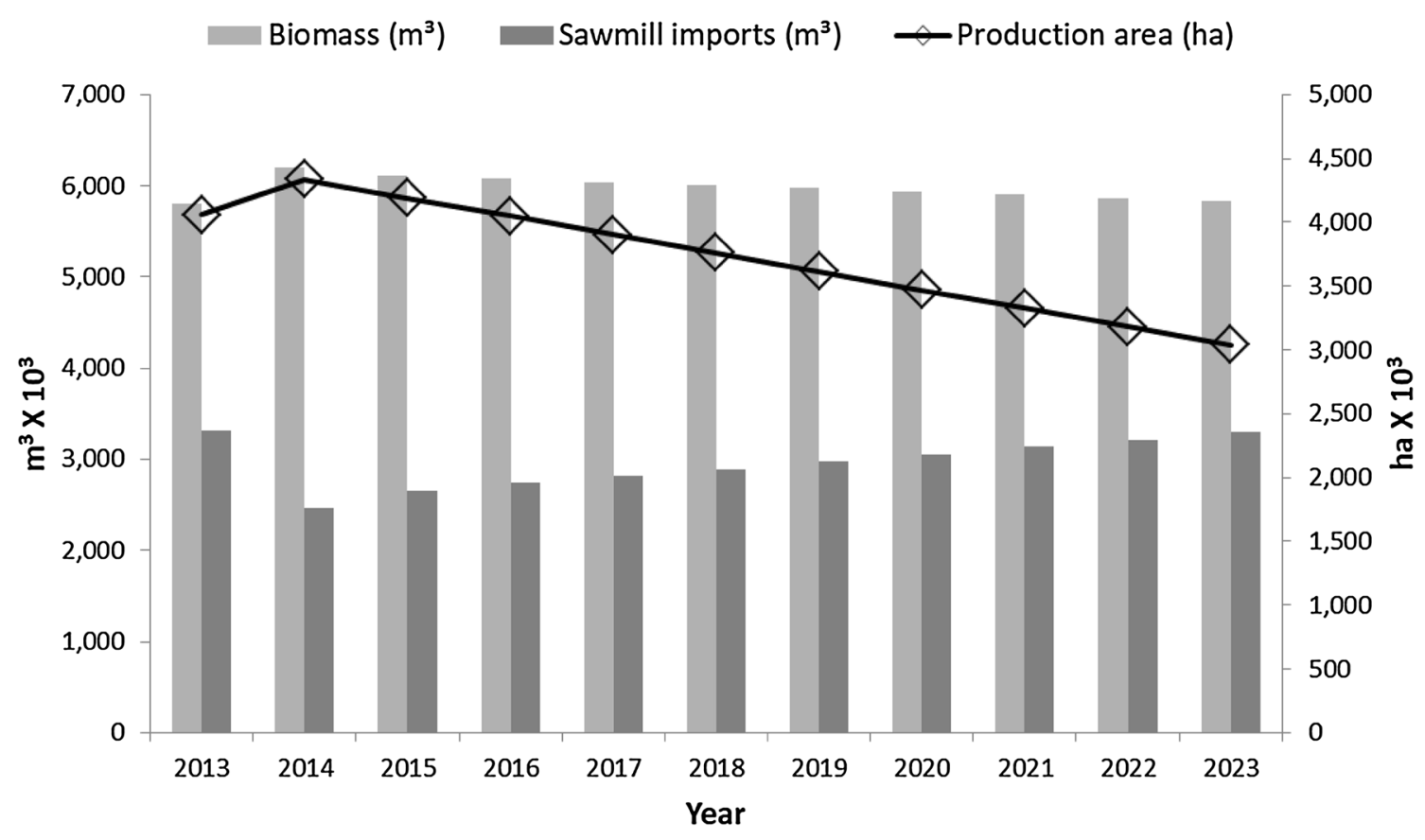

Fig. 2 Predicted forest production areas and availability of forest biomass for energetic use (2014-2023) in scenario A 


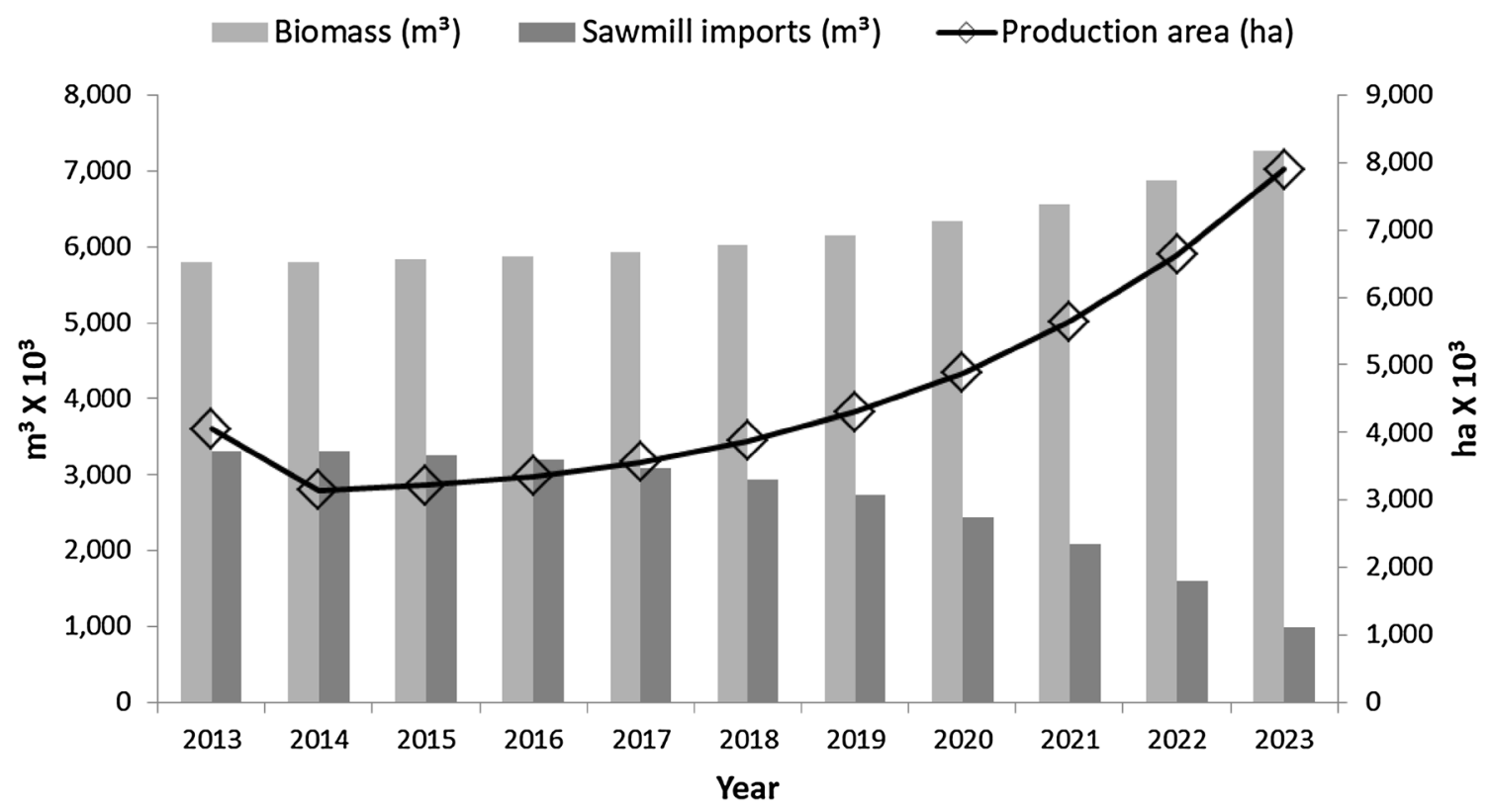

Fig. 3 Predicted forest production areas and availability of forest biomass for energetic use (2014-2023) in scenario B

Step 3: Numerical modeling was run and values for biomass $\left(\mathrm{m}^{3}\right)$ and available energy (PJ) from the analyzed sources and species were obtained. When predicting available forest biomass for energetic use for the year 2023, results showed an increasing trend regarding forest production areas and biomass availability while a decrease in biomass imports was estimated (Fig. 3). Furthermore, an increase in available energy based on forest biomass is expected as a consequence of the increasing number of hectares under sustainable utilization.

The technical potential for year 2023 under scenario B amounted to 7,262,035 $\mathrm{m}^{3}$ and $60.22 \mathrm{PJ}$ as energy output (Tables 6, 7).

\section{Economic Potential}

The economic analysis used the output cost from the Monte Carlo analysis together with official timber prices from 2013 [28], to carry out a net future value analysis for both the northern and central south regions. The costs were grouped according to the three selected biomass sources and simulations were run based on statistical parameters with 100 repetitions each (Tables 8, 9).

Considering the economic flow based on forest woody biomass availability as residues for energy use, the net future value analysis for the year 2023 showed positive values, except for utilizing harvesting residues and nonextracted stands residues in the central south region. As stated before, main timber products coming from the source of non-extracted stands are not included as sold products within the economic analysis. It only considered residues as by-products for energetic use (Table 10).

\section{Discussion}

The presented scenario analysis involved a short-term comparison between the (A) supply of forest woody biomass for energy use under given status quo conditions and (B) the assumption that the number of hectares under sustainable utilization will increase over a period of time.

Considering scenario A, the theoretical and technical availability of forest woody biomass for energetic use decreased over time because of reduced production area. This area reduction could be explained by forest fragmentation and land use change as a continuing trend within the forest sector at a national level. The inadequate application of forest management methods has changed the species composition together with "strong fragmentation problems that influence the low productivity of forest areas and the health of ecosystems" [5]. According to the Land Use and Vegetation Charter Series IV, in 2007 the temperate forests were the most fragmented forest ecosystems in the country with $54 \%$ of its area as fragmented areas [29]. Moreover, "the dynamics of land use change in recent years has followed a pattern that favors the growth of cultivated areas, as well as induced and cultivated pastures over forest areas" [5], therefore reducing the landbase for forest production. Additionally, the current low investment and development of the forest industries also explains this decrease. Imports 
Table 6 Technical availability of woody biomass constrained by soil degradation, slope percentage and mechanization level $\left(\mathrm{m}^{3}\right)$ for 2023 in Scenario B

\begin{tabular}{lrllr}
\hline Source & \multicolumn{1}{l}{ Pine } & Oak & Fir & \multicolumn{1}{l}{ Total } \\
\hline Harvesting residues $\left(\mathrm{m}^{3}\right)$ & & & & \\
$\quad$ North & 825,777 & 367,436 & - & $1,193,213$ \\
Central-south & 574,817 & 330,112 & 173,890 & $1,078,819$ \\
$\quad$ Total & $1,400,594$ & 697,547 & 173,890 & $2,272,032$ \\
Non-extracted stands & & & & \\
$\quad\left(\mathrm{m}^{3}\right)$ & & & & \\
North & 1652 & 8419 & - & 10,071 \\
Central-south & 1810 & 10,450 & 6146 & 18,406 \\
$\quad$ Total & 3462 & 18,869 & 6146 & 28,477 \\
Sawmill residues $\left(\mathrm{m}^{3}\right)$ & & & & \\
$\quad$ North & $1,859,748$ & 223,380 & - & $2,083,128$ \\
$\quad$ Central-south & $1,294,556$ & 200,689 & 390,496 & $1,885,741$ \\
Imports & & & & 992,656 \\
$\quad$ Total & $3,154,304$ & 424,070 & 390,496 & $4,961,526$ \\
Total & & & & $7,262,035$ \\
\hline
\end{tabular}

Table 7 Technically available energy from forest woody biomass (PJ) for 2023 in Scenario B

\begin{tabular}{lcclr}
\hline & Pine & Oak & Fir & Total \\
\hline North & 20.93 & 7.09 & - & 28.03 \\
Central-south & 14.58 & 6.40 & 3.46 & 24.45 \\
Sawmill imports & & & & 7.73 \\
Total & 35.51 & 13.50 & 3.46 & 60.22 \\
\hline
\end{tabular}

of sawmill round wood, on the other hand, were increasing. Furthermore, when analyzing biomass availability within a 10 -year time frame, results showed a change in timber production including a shifting of species, where energy availability based on forest woody biomass residues declined. As the country with the largest number of oak species in the world, Mexico has experienced a significant growth in the oak market over the last 20 years, meaning an increase both in demand and supply [30]. Moreover, the estimated results are highly dependent on national timber production, which has fluctuated over the last two decades and has been affected by imports. For instance, since 2007 production of the three analyzed species has generally decreased with the exception of a slight increase in 2012 and 2013. Back in 1990, national timber production supplied 72\% (8.9 million cubic meters) of the national consumption of forest products. During the following years, this figure decreased considerably and in 2007 national timber supply satisfied only $29 \%$ ( 7 million cubic meters) of national consumption [31]. By the end of 2014, 29\% (5.7 million cubic meters) of national consumption of forest products was supplied through national production [7]. Following this trend, results pointed out an increase of $16 \%$ of residues from imported sawmill timber, meaning a negative growth of the value of the national timber production and a higher trade deficit.

For scenario A, results are a consequence of the trend revealed in the analyzed data over the time series, which at the same time follow the input values of the smoothing parameters. It should be noted that these smoothing parameters have been estimated on the basis that they have the lowest MSE which indicates that the prediction is accurate [27]. As defined by [27], a forecast error is the difference between an observed value and its forecast, meaning the unpredictable part of an observation. When assessing the accuracy of a forecast using MAPE, there is no standard for the estimation of the smoothing parameters which fits every time series. In addition; the accuracy of forecasts can only be determined by considering how well a model performs on new data that were not used when fitting the model [27]. According to the last national official report [7] there is a slight difference between new data and forecasted data from 2016 , with $6,715,284 \mathrm{~m}^{3}$ as real value and $6,081,589 \mathrm{~m}^{3}$ as forecasted value. Therefore, based on the utility function of the model, resulting values from Table 3 are acceptable.

The estimated 46.28 PJ as energy output for year 2023 in scenario A involved an average reduction of $3 \%$ of the energy potential per year where productive areas reduced to $3,181,939$ ha. This implies a stagnation of the forest sector and hinders possible strategies for developing regional economic
Table 8 Monte Carlo simulation results according to cost for the northern region

\begin{tabular}{llll}
\hline Parameter & \multicolumn{2}{l}{ Cost $\left(\mathrm{USD} / \mathrm{m}^{3}\right)$} \\
\cline { 2 - 4 } & Harvesting residues & Non-extracted stands residues & Sawmill residues \\
\hline Min & 11.51 & 15.07 & 7.54 \\
Max & 58.15 & 65.26 & 40.28 \\
Mean & 34.12 & 40.56 & 23.91 \\
SD & 8.19 & 8.50 & 6.85 \\
Confidence interval of 95\% & $33.94 \leq \mathrm{X} \leq 34.30$ & $40.37 \leq \mathrm{X} \leq 40.74$ & $23.78 \leq \mathrm{X} \leq 24.04$ \\
Range & 46.64 & 50.19 & 32.74 \\
Standard error & $0.81 \%$ & $0.69 \%$ & $0.83 \%$ \\
Number of simulations $(\mathrm{N})$ & 7852 & 8242 & 10,784 \\
\hline
\end{tabular}


Table 9 Monte Carlo simulation results according to cost for the central south region

\begin{tabular}{llll}
\hline Parameter & \multicolumn{2}{l}{ Cost $\left(\mathrm{USD} / \mathrm{m}^{3}\right)$} & \\
\cline { 2 - 4 } & Harvesting residues & Non-extracted stands residues & Sawmill residues \\
\hline Min & 6.31 & 8.35 & 10.15 \\
Max & 118.91 & 138.47 & 68.54 \\
Mean & 62.38 & 74.94 & 44.62 \\
SD & 18.38 & 19.18 & 12.50 \\
Confidence interval of $95 \%$ & $62.10 \leq \mathrm{X} \leq 62.65$ & $74.66 \leq \mathrm{X} \leq 75.22$ & $44.42 \leq \mathrm{X} \leq 44.82$ \\
Range & 112.60 & 130.12 & 58.40 \\
Standard error & $0.67 \%$ & $0.37 \%$ & $0.44 \%$ \\
Number of simulations $(\mathrm{N})$ & 17,232 & 17,900 & 15,096 \\
\hline
\end{tabular}

Table 10 Net future analysis for analyzed sources according to prices and costs for year 2023

\begin{tabular}{lccl}
\hline Region & $\begin{array}{l}\text { Harvesting } \\
\text { residues (USD/ } \\
\left.\mathrm{m}^{3}\right)\end{array}$ & $\begin{array}{l}\text { Non-extracted stands } \\
\text { and residues (USD/ } \\
\left.\mathrm{m}^{3}\right)\end{array}$ & $\begin{array}{l}\text { Sawmill } \\
\text { residues } \\
\left(\mathrm{USD} / \mathrm{m}^{3}\right)\end{array}$ \\
\hline North & 18.62 & 8.14 & 57.52 \\
Central South & -44.58 & -65.06 & 23.60 \\
\hline
\end{tabular}

cluster based on forest resources. As mentioned, imports from sawmill biomass increased as a result of the presented trend, where, for instance, timber markets from Chile and the United States had a considerable share on the imported timber production [32]. With a decreasing tendency on productive areas and a higher participation of imported timber wood for national consumption over time, the predicted available energy coming from residues of forest woody biomass over a period of 10 years decreased smoothly but continuously.

On the other hand, the document "Competitiveness of the forest sector in Mexico. Tendencies and Perspectives" outlines an objective of increasing areas under forest utilization to up to 16 million ha, plus 2 million ha for plantation forestry, by 2030 [31]. Moreover, there is an estimated potential of having 21 million ha under sustainable forest utilization by 2030 [31]. Based on scenario B, with an assumed conservative annual increase of the managed forest land by 2500 ha, resulted values of year 2023 are consistent with the objectives involving forested areas sustainably managed set by CONAFOR for the year 2030. Regarding energy output, based on results under scenario B at year 2023, there was an increase of $31 \%$ of the energy potential going from $45.96 \mathrm{PJ}$ to $60.22 \mathrm{PJ}$ along the short-term horizon. According to the last reported data from SENER for year 2016 there was a total contribution of $362 \mathrm{PJ}$ of biomass within the national energy supply [33]. For the year 2016, results from the model accounted for additional $46.59 \mathrm{PJ}$ from the selected biomass sources, which corresponded to $13 \%$ increase of the bioenergy supply share. Additionally, under the assumptions of scenario B, imports from sawmill timber showed a considerable decrement by year 2023, implying the strengthening of regional cluster and creation of regional value chains.
Regarding the economic potential, the statistical yearbook of forest production from 2016 reports that the Mexican forestry sector had a Gross Domestic Product (GDP) of 3.16 million USD. The expected development of energy supply chains based on forest woody biomass by the year 2023 is likely to have a positive effect on the GDP of the Mexican forestry sector which in turn would considerably increase its contribution to the national GDP. As forest woody biomass residues have no commercial use within the value chain so far, this is the case for both scenarios. The difference between them is determined by the amount of imports observed in each alternative.

As already mentioned, this analysis only considered forest woody biomass residues, not including stem wood for from non-extracted stands which also have a great impact on the economic indicators. Costs in the central south region could be lowered by integrating the actors and stakeholders involved in the supply chain. This can be achieved through programs supported by local authorities and local regulators which strengthen the development of the industry.

Given a short-term period and based on general analyzed parameters from the model (selected biomass sources, provinces, sustainability constraints) together with historical data and assumptions, recommendations supported by results are presented: According to the simulation carried out for both scenarios, a conservative and continuous increase of forest productive areas is consistent with the achievement of national goals concerning forestry, energy and GHG emissions. This would affect forest woody biomass availability, allowing the creation of regional industry clusters based on forest resources which contribute to the regional development. At the same time, this would reduce dependency on imported timber, positively affecting trade deficit. For the northern region, based on results by year 2023, a total of $4,166,749$ ha under sustainable utilization and $28.03 \mathrm{PJ}$ as energy output were estimated while following this strategy. Positive economic values for year 2023 suggest the use of this money flow to invest in forest structure and forest equipment to improve biomass availability. In the central south region, an extension of forest productive areas up to 
$3,733,987$ ha followed by an investment of the economic flow coming from sawmill residues in strategies for improving harvesting techniques and equipment is recommended to reduce cost and balance economic outputs.

Important limitations of the model are represented by uncertainties concerning climate change conditions and opening of timber markets at international level which highly impact the input and output variables of the analyzed system. In order to deal with uncertainties in the results, the flexibility of the model allows for changes in MAI and the other included variables. When assessing uncertainties due to climate change; for instance; different scenarios with different parameters on MAI, species, terrain conditions (soil and slope percentage) and mechanization level could be evaluated. Furthermore, these limitations affect feasibility of scenarios. For scenario B the accomplishment of national goals and monitoring of policy frameworks related to forestry and energy programs, followed by the opening of bio-economy clusters at regional scale will impact its feasibility. Moreover, based on the last national official report [7], in 2016 there was a total timber production of $6,715,284 \mathrm{~m}^{3}$ from domestic production. The model for scenario $\mathrm{B}$ calculated a timber production of $6,821,944 \mathrm{~m}^{3}$, indicating good accuracy of the model and feasibility of this scenario given short time frame. In regard to the sustainability constraints, the model considered ecological restrictions in terms of land use and forest dynamics including the impact or residues removal on soil conditions and degradation. Projections of biomass availability for energy use should properly review the availability of land resources without hindering conservation strategies [34], together with other ecological impacts not directly analyzed with the presented model. For instances, residues removal can lead to negative impacts on forest growth given a time frame due to increased nutrient extraction [35]. This would also decrease carbon stock and reduce long-term productivity of forests [36]. Thus, for further research, ecological constraints concerning the carbon balance must be analyzed through the life cycle of the product. Moreover, ecological restriction including photosynthetic constraints and the sustainable management of nutrients and water resources must also be taken into account for future research. Moreover, it is important to note that the scope of this study is the estimation of quantitative and economic potential of forest woody biomass for energetic use. An analysis that assesses most adequate and efficient transformation processes and conversion technology is still necessary.

The scenario modeling analysis presented in this paper provided information for decision makers regarding forest utilization and the cost of utilization for biomass supply for energy use. With it, changes of influencing factors such as the extent of production areas, mechanization level and economic flows are analyzed with respect to their impact on timber imports, production, costs and energy availability. Thus, as a decision making tool, the model allows the simulation of alternatives concerning forest utilization criteria in terms of extraction limits restricted by sustainability constraints, harvesting and transportation costs, forest yield and opening of bioenergy markets.

\section{Conclusions}

The presented scenario analysis involved a comparison between a scenario A, comprising the predictability of forest woody biomass given current conditions, and scenario $\mathrm{B}$ which involved an increment of hectares under sustainable utilization, both, over a short-term period of time (2013-2023). Analyses for the predictability of forest woody biomass for energetic use for both scenarios included sustainability constraints (soil degradation, slope percentage, and mechanization level) as extraction limits for estimating biomass potential. For scenario A, Holt-Winters exponential smoothing considered historical data as input for developing the forecast. This historical data was analyzed through a level component, trend, and seasonality parameters, which followed the behavior of variables such as timber demand, population, GDP and timber markets along a time series. Thus, the forecast predicted a value considering the historical evolution of the variables, meaning that these variables are not assumed to stay constant, but instead to change throughout time given the presented inputs. Results in scenario A pointed out that the technical availability of forest woody biomass for energetic use decreased over time, while imports had an increasing tendency.

While simulating extraction limits based on sustainability constraints from 2013 but assuming an increase in the number of hectares within a given time frame, as presented in scenario $\mathrm{B}$, the calculated energy availability is expected to amount to 60.22 PJ by 2023. Furthermore, the net future value analysis for the year 2023 shows that the value of the national timber production is positively affected, except for utilizing harvesting residues and non-extracted stands residues in the central south region. This represented a contribution of 18.62 USD/ $\mathrm{m}^{3}$ for harvesting residues, $8.14 \mathrm{USD} / \mathrm{m}^{3}$ for non-extracted residues and $57.52 \mathrm{USD} / \mathrm{m}^{3}$ for sawmill residues.

With 60.22 PJ and 7.90 million ha under sustainable forest utilization by 2023 , the sustainable forest utilization including bioenergy transformation, which considers local socioeconomic development followed by mitigation strategies and biodiversity conservation, appears to be a feasible option for strengthening the Mexican bio-economy.

Acknowledgements This research project was supported by the Deutscher Akademischer Austauschdienst (DAAD) as part of the scholarship program Forschungsstipendien für Doktoranden und Nachwuchswissenschaftler für mehr als 6 Monate, 2014/15 (57048249). Authors thank the support from the Eva Mayr-Stihl Stiftung for allowing for open access publication of this article. 


\section{Compliance with Ethical Standards}

Conflict of interest The authors declare no conflict of interest. The founding sponsors had no role in the design of the study; in the collection, analyses, or interpretation of data; in the writing of the manuscript, and in the decision to publish the results.

Open Access This article is distributed under the terms of the Creative Commons Attribution 4.0 International License (http://creativeco mmons.org/licenses/by/4.0/), which permits unrestricted use, distribution, and reproduction in any medium, provided you give appropriate credit to the original author(s) and the source, provide a link to the Creative Commons license, and indicate if changes were made.

\section{Appendix A}

\section{Equations to Estimate Available Woody Biomass and Biomass Extraction Limits for Numerical Modeling [15]}

Equation (6) presents the relation between variables to calculate the theoretical available biomass residues from harvesting:

$H_{j}=\sum_{i=1}^{n} \frac{P_{i j}}{\left(1-C_{i}\right)} \times C_{i}$

where $H$ is the theoretical available biomass residues from harvesting $\left(\mathrm{m}^{3}\right), P$ is the utilized volume of the harvested timber $\left(\mathrm{m}^{3}\right), C$ is the coefficient from harvesting residues and $i$ is the analyzed species out of a $n$ number of species within a $j$ region.

Equation (7) was used to obtain available biomass from the non-extracted stands residues:

$N E_{j}=\sum_{i=1}^{n}\left[\frac{\left(H_{i j}+P_{i j}\right) \times C n e_{i}}{1-C n e_{i}}\right] \times C_{i}$

where $N E$ is the non-extracted stands biomass residues $\left(\mathrm{m}^{3}\right)$, $H$ is the theoretical available biomass residues from harvesting $\left(\mathrm{m}^{3}\right), P$ is the utilized volume of harvested timber $\left(\mathrm{m}^{3}\right)$, $C$ is the coefficient from harvesting residues, $C n e$ is the coefficient of non-extracted stands residues and $i$ is the analyzed species out of a $n$ number of species within a $j$ region.

Equation (8) estimates the theoretical available biomass for energetic use from sawmill residues:

$S m_{j}=\sum_{i=1}^{n}\left[\frac{P_{i j}}{T_{i}} \times S w_{i}\right] * C s_{i}$

where $\mathrm{Sm}$ is the biomass theoretically available from sawmill residues $\left(\mathrm{m}^{3}\right), P$ is the utilized volume of harvested timber $\left(\mathrm{m}^{3}\right), T$ is the total national timber production $\left(\mathrm{m}^{3}\right), S w$ is the sawn wood production $\left(\mathrm{m}^{3}\right), C s$ is the coefficient from sawmills residues and $i$ is the analyzed species out of a $n$ number of species in a $j$ region.
In order to calculate the total chemical and physical degraded forested hectares by region and degradation degree, Eqs. $(9-12)$ explain the calculations based on the relation between total forested area, areas affected by soil degradation at a national scale and soil degradation by vegetation type at a national scale.

$\operatorname{Dslight}_{j}=\sum_{i=1}^{n} F a_{i} \times P S_{\text {slight }} \times S_{i j}$

Dmoderate $_{j}=\sum_{i=1}^{n} F a_{i} \times P S_{\text {moderate }} \times S_{i j}$

Dsevere $_{j}=\sum_{i=1}^{n} F a_{i} \times P S_{\text {severe }} \times S_{i j}$

$D_{\text {tot }}=\sum_{i=1}^{n}\left(D_{\text {slight }}+D_{\text {moderate }}+D_{\text {severe }}\right)$

where Dslight is the slightly degraded forest area (ha), Dmoderate is the moderately degraded forest area (ha), Dsevere is the severely degraded forest area (ha), Dtot is the degraded forest area at a regional level (ha), $F a$ is the total forested area (ha), $P S$ is the percentage of area affected by soil degradation in temperate and cloud forest at a national scale, $S$ is the soil degradation percentage (chemical or physical) in temperate and cloud forest at national scale, $n$ is the number of provinces involved in the analyzed region, $i$ refers to the current province being analyzed and $j$ is the type of soil degradation, either chemical or physical.

Equations (13) and (14) explain the logic behind the calculations of available biomass factors constrained by soil degradation.

Bslight $_{i}=\left[\frac{T f-D_{t o t}+D_{\text {slight }}}{T f}\right] \times$ Erslight $_{i}$

Bmoderate $_{i}=\left[\frac{D_{\text {moderate }}}{T f}\right] \times$ Ermoderate $_{i}$

where $B$ is the available biomass factor constrained by soil degradation, $T f$ refers to the total forested area of the region (ha), $E r$ is the maximum extraction rate according to scale and $i$ refers either to chemical or physical degradation. Equation (A8) includes areas with no degradation, which have an extraction limit of $70 \%$. This is reflected by subtracting the total degraded hectares from the total forested area, thus, where no degradation is observed only $70 \%$ of the theoretical available biomass can be utilized for energetic use. 


\section{Appendix B}

See Fig. 4.

Fig. 4 Analyzed provinces according to region and slope classes

\section{Northern region}

1. Chihuahua

2. Durango

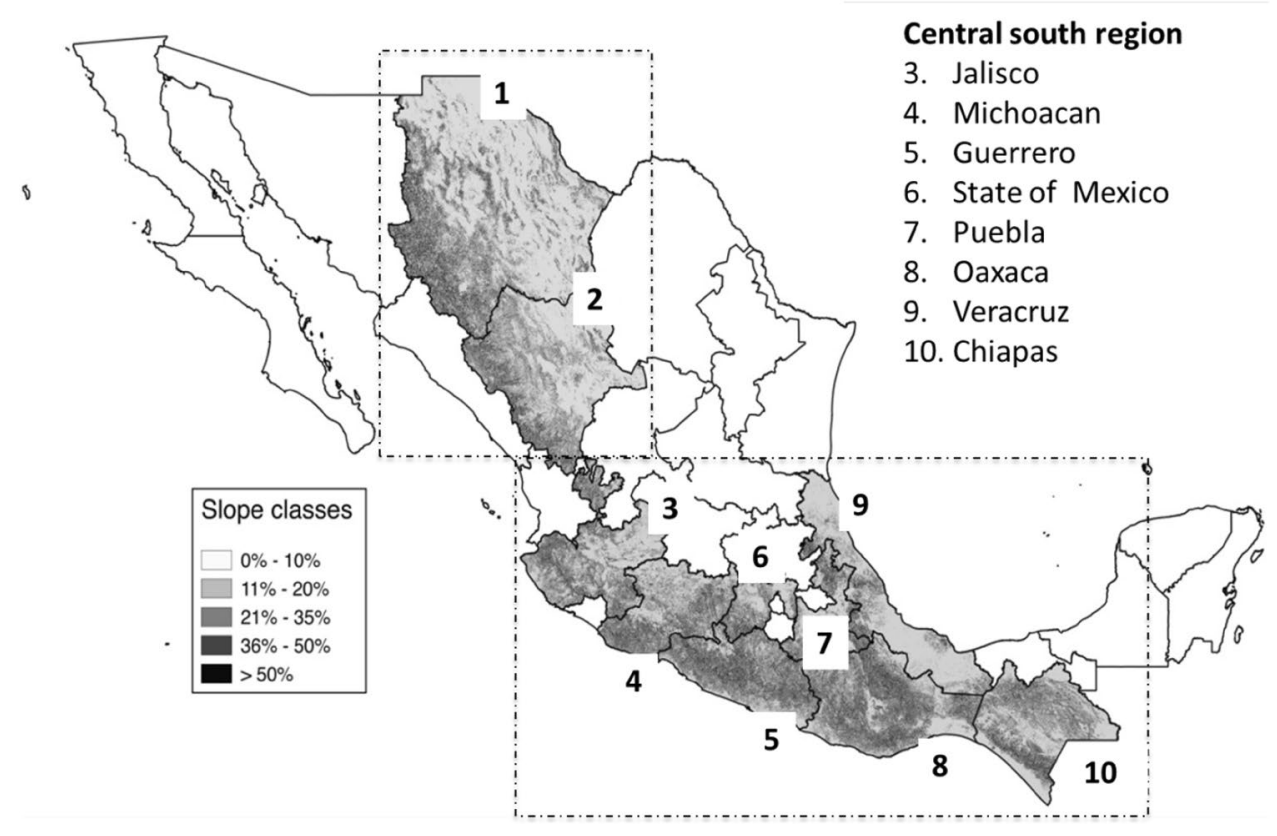

\section{References}

1. Secretaría de Energía SENER: Prospectiva de Petróleo Crudo y Petrolíferos. Secretaría de Energía. Mexico (2013). https://www. gob.mx/cms/uploads/attachment/file/62951/Prospectiva_de_Petr_ leo_y_Petrol_feros_2013-2027.pdf

2. Secretaría de Energía S.E.N.E.R.: Estrategia Nacional de Energía. Mexico (2013). http://climateobserver.org/wpcontent/uploa ds/2014/08/Mexico_Estrategia-Nacional-de-Energia_2013-2027. pdf

3. Secretaría de Energía SENER: Prospectiva de Energías Renovables. Secretaría de Energía. Mexico (2013). https://www.gob. mx/cms/uploads/attachment/file/62948/Prospectiva_de_Energ as_Renovables_2013-2027.pdf

4. Comisión Nacional Forestal CONAFOR: Inventario Nacional Forestal y de Suelos. Informe 2004-2009. Comisión Nacional Forestal CONAFOR. Jalisco, Mexico (2012). http://www.ccmss .org.mx/descargas/Inventario_nacional_forestal_y_de_suelo s_informe_2004_-_2009_.pdf

5. Torres, J.: Estudio de tendencias y perspectivas del Sector Forestal en América Latina Documento de Trabajo. Informe Nacional México. Food and Agricultural Organization FAO, Rome (2004)

6. Flores-Magón, H., Garduño-Barahona, M., Arroyo-Cervantes, C., Gómez-Ibarra, E.: Diagnóstico de las Capacidades y Situación Tecnológica del Sector Forestal y Forestal-Industrial del país. Eje 4 innovación y diseño. Universidad de Guadalajara (2014)

7. Secretaría del Medio Ambiente y Recursos Naturales SEMARNAT: Anuarios Estadísticos de la Producción Forestal 1993-2014.
Secretaría del Medio Ambiente y Recursos Naturales SEMARNAT (2015). http://www.semarnat.gob.mx/temas/gestion-ambie ntal/forestal-y-suelos/anuarios-forestales

8. García, C., Riegelhaupt, E., Ghilardi, A., Skutsch, M., Islas, J., Manzini, F., Masera, O.: Sustainable bioenergy options for Mexico: GHG mitigation and costs. Renew. Sustain. Energy Rev. 43, 545-552 (2015)

9. Rios, M., Kaltschmitt, M.: Bioenergy potential in Mexico-status and perspectives on a high spatial distribution. Biomass Convers. Biorefinery 3, 239-254 (2013)

10. Islas, J., Manzini, F., Masera, O.: A prospective study of bioenergy use in Mexico. Energy 32, 2306-2320 (2006)

11. Sacchelli, S., Zambelli, P., Zatelli, P., Ciolli, M.: Biomasfor: an open-source holistic model for the assessment of sustainable forest bioenergy. iFo. Biogeosci. For. 6, 285-293 (2013)

12. Schelhaas, M.J., van Esch, P.W., Groen, T.A., de Jong, B.H.J., Kanninen, M., Liski, J., Masera, O., Mohren, G.M.J., Nabuurs, J., Palosuo, T., et al.: CO2FIX V 3.1-A Modelling Framework for Quantifying Carbon Sequestration in Forest Ecosystems. ALTERRA, Wageningen (2004)

13. Sokhansanj, S., Kumar, A., Turhollow, A.F.: Development and implementation of integrated biomass supply analysis and logistics model (IBSAL). Biomass Bioenergy 30, 838-847 (2006)

14. Masera, O., Guerrero, G., Ghilardi, A., Velázquez, A., Mas, J., Ordoñez, M.D.J., Drigo, R., Trossero, M.A.: Fuelwood "Hot Spots" in Mexico: A case study using WISDOM-Woodfuel Integrated Supply-Demand Overview Mapping. Food and Agriculture Organization, Rome (2004)

15. Flores Hernández, U., Jaeger, D., Islas Samperio, J.: Bioenergy potential and utilization costs for the supply of forest woody 
biomass for energetic use at a regional scale in Mexico. Energies 10, 1192 (2017)

16. Instituto Nacional de Investigaciones Forestales Agrícolas y PecuariasFAP: Determinación del Potencial y Aprovechamiento de los Residuos Forestales en la Producción de Bioenergía y de Especies no Aprovechadas en el Manejo Forestal; Instituto Nacional de Investigaciones Forestales. Agrícolas y Pecuarias INIFAP, Mexico City (2012)

17. Blank, L.T., Tarquin, A.J.: Engineering economy, 5th edn. McGraw-Hill, New York (2002) (McGraw-Hill series in industrial engineering and management science)

18. Cubbage, F., Davis, R., Rodríguez, D., Frey, G., Mollenhauer, R., Kraus, Y.: Competitividad y Acceso a Mercados de Empresas Forestales Comunitarias en México. Programa sobre los Bosques PROFOR. Mexico (2013)

19. Berg, S. (Ed.) Terrain Classification System for Forestry Work. Forest Operations Institute "Skogsarbeiten": Stockholm, Sweden, 1992

20. Manolis, E., Zagas, T., Karetsos, G., Poravou, S.: Spatial limitations in forest biomass harvesting using geographic information system and remote sensing for an ecological and sustainable bioenergy framework. J. Sustain. For. 37, 1-15 (2018). https://doi. org/10.1080/10549811.2018.1469216

21. Secretaría del Medio Ambiente y Recursos Naturales SEMARNAT. Evaluación de la Degradación del Suelo Causada por el Hombre en la República Mexicana; Secretaría del Medio Ambiente y Recursos Naturales SEMARNAT: Mexico City, Mexico, (2003)

22. Rosillo-Calle, F., Woods, J.: The Biomass Assessment Handbook. Bioenergy for a Sustainable Environment; Earthscan, London (2012)

23. World Agroforestry Center, Tree Functional Attributes and Ecological Database. http://db.worldagroforestry.org/

24. Alfares, H.K., Nazeeruddin, M.: Electric load forecasting: literature survey and classification of methods. Int. J. Syst. Sci. 33, 23-34 (2002)

25. Dannecker, L. (ed.): Energy time series forecasting. efficient and accurate forecasting of evolving time series from the energy domain. In: With assistance of Lars Dannecker. Springer Fachmedien Wiesbaden, Wiesbaden, (2015)

26. Taylor, J.W.: Triple seasonal methods for short-term electricity demand forecasting. Eur. J. Oper. Res. 204, 139-152 (2009)
27. Hyndman, R.J., Athanasopoulos, G. (eds.): Forecasting. Principles and Practice, Print edn. OTexts, S.1. (2014)

28. Centro de Negocios Forestales C.E.N.E.F.O.R.: Precios de productos forestales maderables. Reporte trimestral Octubre/Diciembre 2013. Centro de Negocios Forestales CENEFOR (2013). http://www.cnf.gob.mx:8090/snif/portal/economica/sipre

29. Secretaría del Medio Ambiente y Recursos Naturales SEMARNAT: Informe de la situación del medio ambiente en México. Compendio de estadísticas ambientales indicadores clave y de desempeño ambiental. Edición 2012. Secretaría de Medio Ambiente y Recursos Naturales, México (2013)

30. Forster, R., Arguelles, L.A., Kaatz, S., Aguilar, N.: Market Options and Barriers for Community Produced Timber and Sawnwood from Michoacán, Oaxaca, Guerrero, Campeche and Quintana Roo. Forest Trends, University of Quintana Roo, Tropical Rural Latinoamericana and National Forest Commission. Mexico (2004)

31. Puente, A.: Segunda Revisión del Programa Estratégico Forestal para México 2025 y del Programa Nacional Forestal 2001-2006. Competitividad del Sector Forestal de México Tendencias y Perspectivas. Comisión Nacional Forestal CONAFOR; Food and Agricultural Organization FAO, Mexico (2009)

32. Jaakko Pöyry Consulting: Estudio de Prefactibilidad de la Cuenca Industrial Forestal del Golfo de México; Jaakko Pöyry Consulting. Guadalajara, Mexico (2009)

33. Secretaría de Energía SENER: Sistema de Información Energética, Producción de Energía Primaria (2018). http://sie.energ ia.gob.mx/bdiController.do?action $=$ cuadro \&cvecua $=$ IE11C01

34. Strapasson, A., Woods, J., Chum, H., Kalas, N., Shah, N., RosilloCalle, F.: On the global limits of bioenergy and land use for climate change mitigation. GCB Bioenergy. 9, 1721-1735 (2017). https://doi.org/10.1111/gcbb.12456

35. Vanhala, P., Repo, A., Liski, J.: Forest bioenergy at the cost of carbon sequestration? Curr. Opin. Environ. Sustain. 5(1), 41 (2013). https://doi.org/10.1016/j.cosust.2012.10.015

36. Repo, A., Känkänen, R., Tuovinen, J., Antikainen, R., Tuomi, M., Vanhala, P., Liski, J.: Forest bioenergy climate impact can be improved by allocating forest residue removel. GCB Bioenergy 4, 202-212 (2012) 